\title{
THE ANTECEDENTS OF ELECTRONIC WORD OF MOUTH RESPONSES IN HOTEL EXPERIENCE EVALUATION
}

\author{
Basri Rashid $^{1^{\star}}$, Han Chao ${ }^{2}$, Nor Rabiatul Adawiyah Nor Azam ${ }^{3}$ \\ ${ }^{1,3}$ School of Tourism, Hospitality and Event Management, Universiti Utara Malaysia \\ ${ }^{2}$ School of Tourism Management, North Minzu University, Ningxia, China \\ *Corresponding author’s email: basri@uum.edu.my
}

\begin{abstract}
In today's digital information era, it is common for hotels guests to share their visit experience to their acquaintances or public online especially on popular social media platforms. Hence, reviews and experience sharing have moved from the traditional words of mouth to the electronic word of mouth (eWOM). This paper aims to develop and propose a testable research framework for assessing hotel guests' experience and their eWOM responses. Methodically, desk research was carried out by conducting an exhaustive review of past literature to establish a theoretical understanding of hotel experience assessments and to determine the variables and their measurements. Meaningful encounters with the hotel's products and services are summed up as consumption experience in the forms of perceived value and satisfaction. This cumulative experience may entice the guests to upload their responses on digital platforms. Theoretically, the proposed framework reduces the gaps related to the formulation of research constructs for hotel visit experience assessment. Practically, this paper offers hotel operators a testable framework that can guide them in the development of survey materials in order to gain a comprehensive understanding about their guests visit experience assessment and their electronic word-of-mouth response.
\end{abstract}

Keywords: Electronic Word of Mouth (eWOM); Hotel Experience; Perceived Value; Satisfaction

\section{INTRODUCTION}

During their stay at the hotel, guests often encounter and consume the various products and services within the premises. They evaluate whether these products and services met their needs and wants and the outcome is regarded as consumption experience. Essentially, 
hotel experience is the summative perceived performance of the hotel staff, the products, the services and the hotel facilities. Perceived performance is also interpreted as the benefit gained by the guests in the form of perceived value which will lead to the formation of satisfaction or dissatisfaction. Hence perceived value and satisfaction is an important component of guest experience and eventually, the outcome of this experience would dictate their future responses.

Past studies suggested that customer experience assessment is a complex process which involves contextual and subjective variables (Baek et al., 2020). In this case, the complexity of the hotel guest perceived experience is due to the mixture of the tangible and intangible dimensions of the hospitality service. Moreover, the service experience evaluation of a hotel comprises cognitive and affective responses from the consumption of the hotel's products and services. Hence experience is difficult to measure directly. However, a number of literatures asserted that perceived value would be a realistic component to initially measure customer experience responses. Logically the hotel's products, facilities and services that met the guests' requirements would lead to positive perceived value and thus ensure good experience. Nonetheless, the construct of perceived value is debatable. Scholars seem in disagreement on the dimension of perceived value. Thus, the issue shall be enlightened in this paper.

Literally, the preferable result of a consumption or a purchase is satisfaction. There are numerous literatures that confirmed the role of perceived value as the antecedent of satisfaction. The view was established through various convincing empirical studies in the services, tourism and hospitality areas. Therefore, it is plausible to presume that perceived value is influential in the formation of satisfaction. Nonetheless, the outcome of customer consumption went beyond satisfaction. It is common for customers to disseminate their consumption experience to others.

With the advancement of communication technology, customers frequently use the various digital platforms to share their experience. This is a common and convenient method of disseminating information. Additionally, as many of these online platforms are publicly 
accessible, their sharing would be available to the public. The traditional word-of-mouth information dissemination has been replaced electronically and termed as electronic word-ofmouth (eWOM). Nowadays, the electronic word-of-mouth (eWOM) is an important source of information for the customers and for the service providers.

Overall, this paper deliberates the hotel experience process which is illustrated through the relationship among perceived value, satisfaction and electronic word-of-mouth. In this paper, it is hypothesised that the cognitive and affective elements of perceived value would initiate the formation of the hotel guests' experience. It is anticipated that perceived value influences satisfaction and ultimately inflict the hotel guests' electric word-of-mouth responses. The subsequent aim of this paper is to identify the variables and measurement for hotel experience assessment and to establish a research framework for further research. The following sections discuss the various concepts undertaken by various researchers in the tourism, hospitality and consumer behaviour fields that lead to the formation of the research framework.

\section{Hotel Guest Experience}

The hotel guest experience is a complex process, and researchers have suggested that it depends not only on one side but on both operators and guests (Chathoth et al., 2013; Xiang et al., 2015). Regardless of this complexity, hotel managers and investors are expected to decoratively develop the hotel's environment and deliver service performance that are able to make guest experience more memorable; benefiting both guests and the industry. Furthermore, guests usually share their consumption experience on social media platforms which can be disseminated to a wide spectrum of potential customers. This sharing behavior which is called the electronic words of mouth (eWOM) responses is a common behavior by the customer in most business organizations. By understanding the flow of post consumption assessments and responses, industry players would be able to identify elements that are substantial to their guest's experience thus can strategically handle their guests need and wants. 


\section{Perceived Value}

Tadeja (2008) pointed out that hotels can attract or maintain the relationship with guest or customers by understanding their guests' perceived value evaluation and future behavioural responses. Past studies pointed out that perceived value plays a critical role in the formation of a comprehensive consumption experience. In order to ensure the guests received acceptable level of value, the hotel should ensure their products or services are provided at an appropriate standard. Additionally, as a service organisation, the interaction between the customer and the operator during the delivery process is also vital (Tadeja, 2008). As a result, the guests would feel they have received the value from what they have spent. Thus, it should be noted that perceived value is the guests' evaluation of the utility of the products or services provided which ultimately reflected as a comprehensive experience in the hotel.

Perceived value can be simply defined as the consumers' overall perceptions of the usefulness of a product that they received and what is given by the provider (Zeithaml, 1988). This definition is extended to the customer's assessment of the benefit and net worth they gained from a purchase or consumption (Kim et al., 2015; Bajs, 2015). The literatures also point out to perceived value as the customer's overall assessment of the customer's benefit from services or products relative to cost or sacrifice (Kim et al., 2015). The total benefits are a combination of the performing attributes, consist of physical attributes and service attributes (Monroe, 1990) while the total costs include monetary expenditure (Anderson \& Sullivan, 1993) and non-monetary expenditures (Cronin et al., 1997). Similarly, in the hotel industry, perceived value is viewed as the difference between the total benefits gained and the total costs spent by the hotel guests (Jamal et al., 2011). In terms of hotel guest experience, perceived value is described as the appraisal outcomes of the guest based on the interactions and consumption of the diverse products and services during a stay (Baek et al., 2020). Hence, perceived value is seen as a comparison of costs and benefits in relation to the time, money and energy spent. This usually occur during and after the purchase and consumption of related services, products and activities. 
However, there are theoretical disputes whether perceived value is one-dimensional or multi-dimensional. In a one dimensional concept, Zeithaml (1988) proposed the monetary value dimension with price as the basis of customer evaluation. However, some scholars argue that the one-dimensional measurement has great limitations (Raza et al, 2012). Petrick (2004) for example concluded that the one-dimensional customer's overall value construct would not be able to capture the various elements of perceived value. Thus, it is asserted that the multi-dimensional construct would provide a more reliable and valid measurement for perceived value.

Numerous studies were carried out to test the multi-dimensional construct of perceived value. Sweeney \& Soutar (2001) for example introduced PERVAL; the four dimensions of perceived value that claim to offer a more comprehensive measurement of perceived value; namely emotional value; social value; financial value (monetary) and functional value (quality). Petrick (2002) proposed the SER-PERVAL which divide perceived value into five dimensions: quality, emotional response, monetary price, behavioural price, and reputation. This paper views that the multi-dimensional approach is appropriate for perceived value assessment. In this case, the perceived value of hotel services is divided into four dimensions which are financial value, functional value, emotional value and aesthetic value. These variables are adapted from numerous empirical studies such as in Sweeney \& Soutar (2001); Petrick (2004) and Mohsin \& Lockyer (2010) and other studies.

\section{Financial Value}

Literatures noted that financial value is used in various terms. It is termed as "value for money" as comparing the utility of the product compared to the short-term and long-term cost of the consumer (Sweeney \& Soutar, 2001). Xie \& Chen (2014) defined financial value as hard benefits or tangible economic rewards while according to Eid \& El-Gohary (2015) financial value is the price or economic valuations made by individuals. These definitions emphasised the customer's economic gain in comparison with the monetary expenditure. This view of perceived value is relevant to the hotel business as guests often compare the 
worthiness of products and services they received with the amount they spent. Thus in the hotel business, financial value may be referred as the guests' perceived value for money in relation to the related products and services received. The role of financial value as a fundamental element of perceived value has been affirmed in numerous studies (Eid \& ElGohary, 2015; Petrick, 2004; Sweeney \& Soutar, 2001; Ramanathan \& Ramanathan, 2011; Xie \& Chen, 2014). Therefore, financial value shall be utilized as one of the dimensions of perceived value construct.

\section{Functional Value}

Functional value from the customer's view can be defined as the utility derived from the perceived quality and expected performance of the product or service (Sweeney \& Soutar, 2001). Hence it is referred to the quality performance of the products and services delivered to the customers. Bajs (2015) pointed out that the functional value of service quality includes the quality of shopping, food and beverage, entertainment and the staff. Service quality in the experience is derived from the performance standards, and this criterion is composed of the two elements, tangible and intangible service elements (Ramanathan \& Ramanathan, 2011). In the tourism industry, Murphy et al. (2000), for example, agreed that service quality is the primary value affecting perceived value in tourism. In the hotel industry, the functional value of service quality is essentially the guests' perception of the hotel's service quality performance and can influence their experience. Functional value of service quality is also considered as a key factor in determining future behavioral responses such as loyalty (Lee et al., 2011). Conclusively, functional value is another dimension to be included in the perceived value construct.

\section{Emotional Value}

Emotional value can be considered as the post consumption feelings or affective states that a product or service generates. It is the descriptive judgment of consumers after experiencing products and services (Bajs, 2015) that derived from the intangible cognition of 
the customer (Xie \& Chen, 2014). Overall, emotional value can be defined as the pleasure obtained in the usage of a product/service (Özer et al., 2017). Emotional value is an especially important perceived value dimension. A number of research based on discovery of experience found that emotional value played an important role in tourists' future purchase behavior (Eid \& El-Gohary, 2015; Sanchez et al., 2006). Similarly, in the hotel industry, a study by Xie \& Chen (2014) found that psychological (emotional) value significantly impacted hotel loyalty programs. This is noted in a study by Sipe (2018) who concluded that emotional value influence customer experience and is also an important motivator of future behavioral intention for the hotel and tourism industry. Hence, for an unforgettable experience, emotional value is of paramount importance in hotels and tourism (Pizam, 2010). Based on the above reviews, it is plausible to include emotional value as one of the key dimensions of perceived value.

\section{Aesthetic Value}

The service industry attaches great importance to aesthetic value. Typically, the hotel sector recognises that aesthetic value plays a vital role in customer experience. For example, before a hotel guest check-in, the hotel's first impression may be derived from the hotel's overall architectural style. The lobby of the hotel is decorated with the hotel's overall tone. These impressions somehow would have an impact on the hotel guests' experience. Gallarza \& Saura (2006) defined aesthetics as beauty. Referring to hotel, Gallarza et al., (2017) defined aesthetic value as the hotel's visual design response, including hotel atmosphere, hotel architecture and hotel interior design. Keng et al., (2007) agreed that aesthetic value plays a positive role in customer behavioral intention. Moreover, Gallarza \& Saura (2006) suggested the aesthetic value is important to accommodation firms. El-Adly (2019) affirmed that one of the most decisive influence on hotel guest experience is the aesthetic value (especially in the restaurant environment). This result is consistent with Sulek \& Hensley (2004) study, who noted that the hotel environment (restaurant lighting, atmosphere, style, etc.) can enhance the hotel guest experience. Overall, the hotel industry considered aesthetics to be a dimension of perceived value. This finding confirmed the work of other researchers (El-Adly, 2019; Gallarza 
\& Saura, 2006; Gallarza et al., 2017; Wu \& Liang, 2009). Hence, aesthetics value is adopted as a part of the dimensions of perceived value.

Based on previous discussions, this paper reiterates that guest's perceived value is derived from the consumption experience of relevant products and facilities at the hotel. This later will have an influential effect on their future responses namely satisfaction and eWOM. This relationship has been ascertained in numerous studies which linked customer perceived value with customer satisfaction and (Dehghan et al., 2015; Lemon \& Verhoef, 2016; Wang et al., 2004). Satisfaction is an important element in customer experience which in turn will determine their future responses (Page \& Spreng, 2002; Rashid, 2013; Yüksel \& Rimmington, 1998). The following sections will discuss the construct of satisfaction and customer post satisfaction responses.

\section{Satisfaction}

Satisfaction can be differentiated from perceived value based on their time of occurrence. While it is possible for perceived value to occur at different stages of purchase or consumption, satisfaction however transpire at the post stage of the transaction (Woodruff, 1997). Thus, satisfaction can be regarded as the customer's post consumption attitude towards service providers and conceptualised as an overall outcome of a consumption judgement. This has been acknowledged in numerous past studies that satisfaction can be an outcome of perceived value judgements (Cronin et al., 2000; Eggert \& Ulaga, 2002; GarcíaFernández et al., 2018; Kuo et al., 2009).

Within the service industries, various satisfaction theories and models have been used to study the products and services consumption outcome. These studies include in the hotel industry (Bilgihan et al., 2014), food service industry (Lee et al., 2011) and tourism industry (Zehrer et al., 2014). Theoretically, studies related to customer satisfaction are frequently associated with the expectancy-disconfirmation theory (EDT). This theory is dubbed as the most widely used theory to investigate customer satisfaction assessment (Baker \& Crompton, 2000; Oliver, 1997). According to this theory, satisfaction is seen as a pre-purchase and post- 
use evaluation. In this instance, satisfaction is viewed as an outcome of the customer's comparison between their expectation and the actual performance of the products and services (Oliver, 1997; Yuksel \& Rimmington, 1998). Satisfaction emerged if the outcome matches or exceeds the customer's expectations but if the product or service performance is less than their expectations, customers are dissatisfied.

However, the expectancy-disconfirmation paradigm may only be applicable if the customers had a predetermined expectation for related products and services before consumption. Thus, if the products and services were unknown or unfamiliar with the customer, expectation would not be possible. Hence, in some situations, it would be inappropriate to evaluate satisfaction using this paradigm.

Efforts to overcome the expectancy-disconfirmation paradigm had been carried out in a number of studies. The most noted study was by Yuksel \& Rimmington (1998) which attempted to determine the most reliable model to measure customers' satisfactions. They examined six alternative models namely performance only, important-performance, importance minus performance, direct confirmation-disconfirmation, confirmationdisconfirmation weighted by importance, and performance minus predictive expectation. It was concluded that the performance model offers a better framework for measuring customer satisfaction. The performance model refers to measures that are based only on customers' perceptions of the performance of the product and service, as opposed to the difference between the customers' perceived expectation and actual performance of the product and service. Their finding was further affirmed and applied in various service industries (Brady et al., 2002; Cronin \&Taylor, 1992; Kim et al., 2015; Page \& Spreng, 2002; Patwary \& Rashid, 2016; Yuksel \& Rimmington, 1998). Therefore, this paper support the notion that perceived performance model is the most appropriate predictor to study satisfaction when it is difficult to measure customer expectation.

Satisfaction usually trigger numerous behavioural actions such as revisit, recommendation and word of mouth. Current technology has encouraged consumers to use 
electronic medium to share their experience with public. This form of communication is regarded as electronic word or mouth (eWOM) communication. Evident from past studies pointed out that satisfaction may have a direct positive impact on electronic word or mouth responses (Oliver, 2014; Kim \& Kim, 2017). Hence, it is logical to deduce that satisfaction is the antecedent of electronic word or mouth.

\section{Electronic Word-of-Mouth (eWOM)}

Generally, word-of-mouth (WOM) can be defined as an informal person-to-person communication between consumers about specific product, service or company (HueteAlcocer, 2017; Westbrook, 1987). This form of communication is seen as one of the information sources used by many customers in their purchase decision making process. In addition, information from this communication may be used by customers to perceive any brand, product or service.

Due to the advancement in communication technology, various digital communication platforms are available for users to express their thoughts. These online platforms (e.g., social media, blogs, etc.) are a common medium for customers to disseminate their post consumption experiences to the public. Hence, the term "electronic word-of-mouth" (eWOM) exists (Buhalis \& Law, 2008; Huete-Alcocer, 2017). Electronic word-of-mouth (eWOM) can be defined as all informal communications to consumers through web-based technologies. The eWOM is regarded as a new form of online WOM communication where customers can post their comments i.e. thoughts, ideas and feelings about products and services on various online platforms (Augusto de Matos et al., 2009; Huete-Alcocer, 2017; Moliner-Velázquez et al., 2015; Schindler \& Bickart, 2005; Yang, 2017). This digital environment can be dubbed as an innovative and a convenient source to gather required information. Consequently, it has become an important and influential source of information for both the buyers and the sellers.

The influence of eWOM towards customer decision making may be substantial compared to the traditional word-of-mouth due to the extensive coverage and the high distribution speed of the information on the electronic medium. Thus, the eWOM expands the 
customer's choice of collecting and disseminating information about products and services from sellers. Potential customers, may use eWOM as supporting information in their purchasing decision while for current customers, the digital platform is the place they express their post consumption experience. As for the sellers the eWOM can be one of the venues to lean about their customers' responses.

In the tourism industry, travellers are increasingly aware of the online feedbacks as supporting information to plan their travelling ideas, plans and travelling-related decisions. Travellers are turning to eWOM for more travel-related information which eventually influence visit intention, tour choices and other travel related behaviour (Amaro \& Duarte, 2013; Wang 2015). According to King et al. (2014), the relationship between customers' eWOM and online responses is similar in the hotel industry but somehow, appeared to be stronger than the tourism industry. The eWOM may eventually influence guests' perception about the hotel and their future responses. It is noted that positive online reviews improved the perception of hotels among potential consumers (Vermeulen \& Seegers, 2009). Nonetheless, the intangible nature of hotel experience may lead to feeling of pre-visit uncertainty among potential guests; thus, they opt to find relevant information from online sources particularly comments from previous guests. This behaviour is affirmed in a study by Sotiriadis \& Van Zyl (2013) who reported that hotel guests displayed significant interest towards eWOM. In a study by Yen \& Tang (2019), it is noted that only $3.17 \%$ of hotel guests never share their experience online while the other $98.83 \%$ guests would somehow share their experience online. Therefore, it is sufficed to postulate that hotel guests are increasingly involved with the eWOM either to share their experience or to use it as their source of information.

\section{METHODS}

Methodically, past studies related to post consumption experience within the service, tourism and hospitality areas including the hotel industry were extensively reviewed and scrutinised. The focus of the reviews is on the construct of post visit experience and the future 
responses. A number of elements emerge from the reviews particularly the role of perceived value and satisfaction in hotel experience as well as the post experience responses in the forms of electronic words of mouth. In specific, evident from the literature suggest that post consumption experience of hotel guests can be depicted through the relationship among a number of constructs namely perceived value, satisfaction and electronic word-of-mouth. The plausible result of this paper is a testable research framework that can be used to guide researchers and practitioners in order to understand the visit evaluation process and post consumption responses.

\section{RESULT - CONSTRUCTION OF THE MEASUREMENT AND FRAMEWORK}

Based on the literature review, this paper proposes the four dimensions of perceived value constructs namely; financial value, functional value of service quality, emotional value and aesthetic value. These dimensions are expected to influence hotel guests' satisfaction and electronic word-of-mouth responses. The measurements used to assess each of the dimension are presented in Table 1.

Table 1. Measurement Items, Scale and Sources of Perceived Value

\begin{tabular}{|c|c|c|c|}
\hline Constructs & Measurement Items/keywords & Scale & Source \\
\hline $\begin{array}{l}\text { Financial value } \\
\text { (4 items) }\end{array}$ & $\begin{array}{l}\text { Economical; } \\
\text { - Reasonable price; } \\
\text { - Value for money; } \\
\text { - Good purchase for the price. }\end{array}$ & $\begin{array}{l}\text { 5-point Likert } \\
\text { scale }\end{array}$ & $\begin{array}{l}\text { Sweeney \& Soutar, } \\
\text { 2001; Petrick, 2004; } \\
\text { Mohsin \& Lockyer, 2010; } \\
\text { Xie \& Chen, 2014; Eid \& } \\
\text { El-Gohary, 2015 }\end{array}$ \\
\hline $\begin{array}{l}\text { Functional value } \\
\text { of service quality } \\
\text { ( } 5 \text { items) }\end{array}$ & $\begin{array}{l}\text { - Acceptable standard of service } \\
\text { quality; } \\
\text { - Prompt service; } \\
\text { - Reliable and accurately } \\
\text { - service; } \\
\text { - Staff kindness and friendliness; } \\
\text { - Consistent service quality level. }\end{array}$ & $\begin{array}{l}\text { 5-point Likert } \\
\text { scale }\end{array}$ & $\begin{array}{l}\text { Sweeney \& Soutar, } \\
\text { 2001; Petrick, 2004; } \\
\text { Sanchez et al., 2006; } \\
\text { Bajs, } 2015\end{array}$ \\
\hline $\begin{array}{l}\text { Emotional value } \\
\text { (5 items) }\end{array}$ & $\begin{array}{l}\text { - Pleasure; } \\
\text { - Feeling good; } \\
\text { - Relaxation; } \\
\text { - Enjoyment; } \\
\text { - Comfortable. }\end{array}$ & $\begin{array}{l}\text { 5-point Likert } \\
\text { scale }\end{array}$ & $\begin{array}{l}\text { Sweeney \& Soutar, } \\
\text { 2001; Petrick, 2004; Eid } \\
\text { \& El-Gohary 2015; Bajs, } \\
2015\end{array}$ \\
\hline $\begin{array}{l}\text { Aesthetic value } \\
\text { (6 items) }\end{array}$ & $\begin{array}{l}\text { - Appealing furnishing } \\
\text { - Impressive architecture } \\
\text { - Distinctive decoration } \\
\text { - Pleasant odour scheme } \\
\text { - Appealing colour scheme } \\
\text { - Appropriate lighting }\end{array}$ & $\begin{array}{l}\text { 5-point Likert } \\
\text { scale }\end{array}$ & $\begin{array}{l}\text { Wu \& Liang, 2009; } \\
\text { Gallarza et al., 2016; } \\
\text { Gallarza et al., 2017 }\end{array}$ \\
\hline
\end{tabular}


Past studies have acknowledged that, customer satisfaction is a post-purchase judgment that leads to an overall feeling about a particular transaction. Supported by numerous researchers (Alegre \& Cladera, 2006; García-Fernández et al., 2018; Kim et al., 2015; Lee et al., 2011), the single overall measurement is seen as an appropriate indicator of satisfaction. Hence the single one item overall questions are adopted to measure satisfaction. In this case, satisfaction with the hotel experience is deemed to be measured on a scale of 1 to 5 , using scale 1 = "extremely dissatisfied" to scale 5 = "extremely satisfied".

Measurement items for electronic word-of-mouth of hotel guests were adapted from past studies (Augusto de Matos et al., 2009; Moliner-Velázquez et al., 2015). Three items were selected namely: 1. "Say positive things to other people on online platform"; 2. "Recommend to others on online platform"; and 3. "Tell my friends and relatives through on online platform". The questions are measured on the 5 -point Likert scale from $1=$ "strongly disagree" to $5=$ "strongly agree".

It has been deliberated that numerous studies have verified the relationship between perceived value, satisfaction and eWOM (Dehghan et al., 2015; García-Fernández et al., 2018; Lemon \& Verhoef, 2016; Özer et al., 2017; Wang et al., 2004). Perceived value is posited as the customer's overall assessment of net worth which is derived from the assessment of the customer's benefit from services or products relative to the sacrifice made (Kim et al., 2015). Perceived value is a beneficial tool to assess the effectiveness of a product (or service) delivery process and the customers post consumption outcome. Perceived value is depicted as a construct from a multiple dimensions namely financial value, functional value, emotional value and aesthetic value. These variables are expected to influence guest satisfaction. This view is supported by various studies that attested perceived value as the antecedent of satisfaction (Eggert \& Ulaga, 2002; Kuo et al., 2009; Williams \& Soutar, 2009).

The literature on consumer satisfaction largely agrees that satisfaction can be seen as the overall and positive emotion produced by consumers' cognitive evaluation of their experience, which refers to the measurement of the performance of related products and service attributes (Baker \& Crompton, 2000; Hwang \& Seo, 2016). Eventually, satisfaction will 
lead to customers' responses such as repurchase, revisit, recommend and word-of-mouth (Yuksel \& Rimmington, 1998; Murphy et al., 2000; Page \& Spreng, 2002; Rashid, 2013).

Conclusively, the relationship between perceived value, satisfaction and eWOM can be drawn. Perceived value is expected to influence satisfaction and that satisfaction in turn will influence eWOM. Satisfaction stands in between these constructs (perceived value and eWOM) which implies the mediating role of satisfaction between perceived value and eWOM. Hence, a research framework to study hotel guest experience assessment as depicted in Figure 1 is developed.

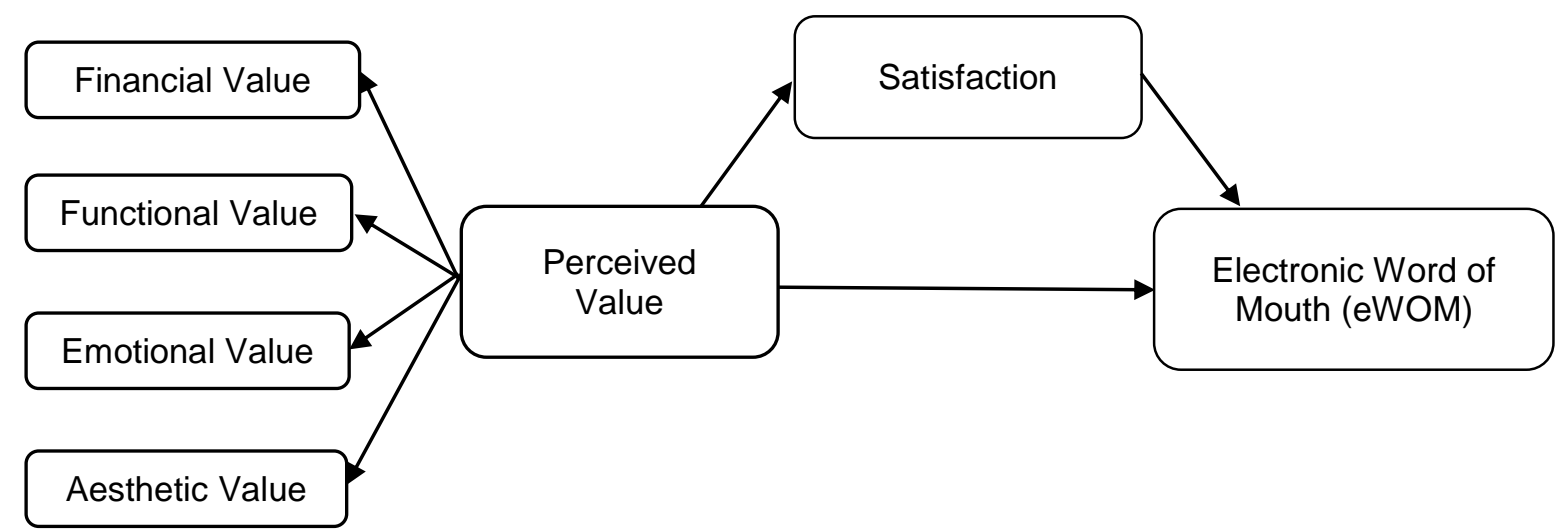

Figure 1. Research Framework

The research framework (Figure 1) illustrates perceived value, satisfaction and EWOM as the testable variables to study hotel guests post visit assessment and responses. It examines the influence of hotel guest perceived value on satisfaction and eWOM. Satisfaction in return influence guests' eWOM responses. In terms of classification, perceived value is an independent variable while eWOM id the dependent variable. Satisfaction can be seen as a mediator between perceived value and eWOM. Ultimately, a number of research propositions can be made based from the discussions in this paper and as depicted in the framework:

Proposition 1: Perceived value influences satisfaction.

Proposition 2: Perceived value influences eWOM.

Proposition 3: Satisfaction influences eWOM.

Proposition 4: Satisfaction mediate the relationship between perceived value and eWOM. 
It should be reiterated that the objective of this paper is to identify the antecedents of eWOM and propose a testable research framework to assess hotel guests visit experience. Having achieved this objective, it is recommended that further study is carried out to test the construct validity and reliability of the proposed framework before a full investigation can be conducted.

\section{CONCLUSION}

This paper advocates that customer experience is a result from a comprehensive postconsumption assessment of perceived value responses. This assessment method is deemed applicable to the hotel industry. At the initial stage of the guest experience evaluation, perceived value and satisfaction play a very important role to generate memorable experience. Ultimately, in line with current electronic advancement the guests are expected to use online platforms to disseminate their experience. Theoretically, the framework reduces the gaps in the literature related to the formulation of research constructs for hotel visit experience assessment. Practically, the framework is beneficial to hotel operators or relevant stakeholders in order to gain a comprehensive understanding about hotel guests' visit experience responses and their word of mouth responses, particularly using electronic communication medium (eWOM). Nonetheless, the framework should be tested in order to confirm its robustness.

\section{REFERENCES}

Augusto de Matos, C., Vargas Rossi, C. A., Teixeira Veiga, R., \& Afonso Vieira, V. (2009). Consumer reaction to service failure and recovery: the moderating role of attitude toward complaining. Journal of Services Marketing, 23(7), 462-475.

Alegre, J., \& Cladera, M. (2006). Repeat visitation in mature sun and sand holiday destinations. Journal of Travel Research, 44(3), 288-297.

Amaro, S., \& Duarte, P. (2013). Online travel purchasing: A literature review. Journal of Travel \& Tourism Marketing, 30(8), 755-785.

Anderson, E. W., \& Sullivan, M. W. (1993). The antecedents and consequences of customer satisfaction for firms. Marketing science, 12(2), 125-143.

Baek, J., Choe, Y., \& Ok, C. M. (2020). Determinants of hotel guests' service experiences: an examination of differences between lifestyle and traditional hotels. Journal of Hospitality Marketing \& Management, 29(1), 88-105. 
Bajs, I. (2015). Tourist perceived value, relationship to satisfaction, and behavioral intentions: The example of the Croatian tourist destination Dubrovnik", Journal of Travel Research, 54(1), $122-134$.

Baker, D. A., \& Crompton, J. L. (2000). Quality, satisfaction and behavioral intentions. Annals of tourism research, 27(3), 785-804.

Bilgihan, A., Okumus, F., Nusair, K., \& Bujisic, M. (2014). Online experiences: flow theory, measuring online customer experience in e-commerce and managerial implications for the lodging industry. Information Technology \& Tourism, 14(1), 49-71.

Brady, M. K., Cronin Jr, J. J., \& Brand, R. R. (2002). Performance-only measurement of service quality: a replication and extension. Journal of Business Research, 55(1), 17-31.

Buhalis, D., \& Law, R. (2008). Progress in information technology and tourism management: 20 years on and 10 years after the Internet - The state of e-Tourism research. Tourism Management, 29(4), 609-623.

Chathoth, P., Altinay, L., Harrington, R. J., Okumus, F., \& Chan, E. S. (2013). Co-production versus co-creation: A process based continuum in the hotel service context. International Journal of Hospitality Management, 32, 11-2.

Cronin Jr, J. J., \& Taylor, S. A. (1992). Measuring service quality: a re-examination and extension. The Journal of Marketing, 55-68.

Cronin Jr, J. J., Brady, M. K., \& Hult, G. T. M. (2000). Assessing the effects of quality, value, and customer satisfaction on consumer behavioral intentions in service environments. Journal of Retailing, 76(2), 193-218.

Cronin, J. J., Brady, M. K., Brand, R. R., Hightower Jr, R., \& Shemwell, D. J. (1997). A crosssectional test of the effect and conceptualization of service value. Journal of Services Marketing, 11(6), 375-391.

Dehghan, A. N., Alizadeh, H., \& Mirzaei-Alamouti, S. (2015). Exploring the customer perceived values as antecedent of purchase behaviour. Serbian Journal of Management, 10(2), 173-188.

Eggert, A., \& Ulaga, W. (2002). Customer perceived value: a substitute for satisfaction in business markets?. Journal of Business \& Industrial Marketing, 17(2/3), 107-118.

Eid, R., \& El-Gohary, H. (2015). Muslim tourist perceived value in the hospitality and tourism industry. Journal of Travel Research, 54(6), 774-787.

El-Adly, M. I. (2019). Modelling the relationship between hotel perceived value, customer satisfaction, and customer loyalty. Journal of Retailing and Consumer Service, 50, 322332.

Gallarza, M. G., \& Saura, I. G. (2006). Value dimensions, perceived value, satisfaction and loyalty: an investigation of university students' travel behaviour. Tourism Management, 27(3), 437-452.

Gallarza, M. G., Arteaga, F., Del Chiappa, G., Gil-Saura, I., \& Holbrook, M. B. (2017). A multidimensional service-value scale based on Holbrook's typology of customer value: bridging the gap between the concept and its measurement. Journal of Service Management, 28(4), 724-762.

García-Fernández, J., Gálvez-Ruíz, P., Fernández-Gavira, J., Vélez-Colón, L., Pitts, B., \& Bernal-García, A. (2018). The effects of service convenience and perceived quality on perceived value, satisfaction and loyalty in low-cost fitness centers. Sport Management Review, 21(3), 250-262.

Huete-Alcocer, N. (2017). A literature review of word of mouth and electronic word of mouth: Implications for consumer behavior. Frontiers in Psychology, 8, 1256.

Hwang, J., \& Seo, S. (2016). A critical review of research on customer experience management: Theoretical, methodological and cultural perspectives. International Journal of Contemporary Hospitality Management, 28(10), 2218-2246.

Jamal, S. A., Othman, N. A., \& Muhammad, N. M. N. (2011). Tourist perceived value in a community-based homestay visit: An investigation into the functional and experiential aspect of value. Journal of Vacation Marketing, 17(1), 5-15.

Keng, C. J., Huang, T. L., Zheng, L. J., \& Hsu, M. K. (2007). Modelling service encounters and customer experiential value in retailing: An empirical investigation of shopping mall 
customers in Taiwan. International Journal of Service Industry Management, 18(4), 349367.

Kim, L. H., \& Kim, D. J. (2017). Achieving relational outcomes in casual dining restaurants through consumer commitment. Current Issues in Tourism, 20(2), 178-203.

Kim, Y. H., Duncan, J., \& Chung, B. W. (2015). Involvement, satisfaction, perceived value, and revisit intention: A case study of a food festival. Journal of Culinary Science and Technology, 13(2), 133-158

King, R. A., Racherla, P., \& Bush, V. D. (2014). What we know and don't know about online word-of-mouth: A review and synthesis of the literature. Journal of Interactive Marketing, 28(3), 167-183.

Kuo, Y. F., Wu, C. M., \& Deng, W. J. (2009). The relationships among service quality, perceived value, customer satisfaction, and post-purchase intention in mobile valueadded services. Computers in Human Behavior, 25(4), 887-896.

Lee, J. S., Lee, C. K., \& Choi, Y. (2011). Examining the role of emotional and functional values in festival evaluation. Journal of Travel Research, 50(6), 685-696.

Lemon, K. N., \& Verhoef, P. C. (2016). Understanding customer experience throughout the customer journey. Journal of Marketing, 80(6), 69-96.

Mohsin, A., \& Lockyer, T. (2010). Customer perceptions of service quality in luxury hotels in New Delhi, India: an exploratory study. International Journal of Contemporary Hospitality Management, 22(2), 160-173.

Moliner-Velázquez, B., Ruiz-Molina, M. E., \& Fayos-Gardó, T. (2015). Satisfaction with service recovery: moderating effect of age in word-of-mouth. Journal of Consumer Marketing, 32(6), 470-484.

Monroe, K. B. (1990). Pricing: Making profitable decisions. McGraw-Hill, New York.

Murphy, P., Pritchard, M. P., \& Smith, B. (2000). The destination product and its impact on traveller perceptions. Tourism Management, 21(1), 43-52.

Oliver, R. L. (2014). Satisfaction: A behavioral perspective on the consumer. (2nd Ed.). Routledge, New York.

Oliver, C. (1997). Sustainable competitive advantage: combining institutional and resourcebased views. Strategic Management Journal, 18(9), 697-713.

Özer, L., Başgöze, P., \& Karahan, A. (2017). The association between perceived value and patient loyalty in public university hospitals in Turkey. Total Quality Management \& Business Excellence, 28(7-8), 782-80.

Page Jr, T. J., \& Spreng, R. A. (2002). Difference scores versus direct effects in service quality measurement. Journal of Service Research, 4(3), 184-192.

Patwary, A. K., \& Rashid, B. (2016). The impacts of hospitality services on visit experience and future visit intention of student travellers. International Journal of Business and Technopreneurship, 6(8), 107-125.

Petrick, J. F. (2002). Development of a multi-dimensional scale for measuring the perceived value of a service. Journal of Leisure Research, 34(2), 119-134.

Petrick, J. F. (2004). The roles of quality, value, and satisfaction in predicting cruise passengers' behavioral intentions. Journal of Travel Research, 42(4), 397-407.

Pizam, A. (2010) Creating memorable experience. International Journal of Hospitality Management, 29(3), 343.

Ramanathan, U., \& Ramanathan, R. (2011). Guests' perceptions on factors influencing customer loyalty: An analysis for UK hotels. International Journal of Contemporary Hospitality Management, 23(1), 7-25.

Rashid, B. (2013). Post Visit Assessment: The influence of consumption emotion on tourist future intention. Journal of Business and Management, 9(3), 39-45

Raza, M. A., Siddiquei, A. N., Awan, H. M., \& Bukhari, K. (2012). Relationship between service quality, perceived value, satisfaction and revisit intention in hotel industry. Interdisciplinary Journal of Contemporary Research in Business, 4(8), 788-805.

Sanchez, J., Callarisa, L., Rodriguez, R. M., \& Moliner, M. A. (2006). Perceived value of the purchase of a tourism product. Tourism Management, 27(3), 394-409. 
Schindler, R. M., \& Bickart, B. (2005). Published word of mouth: Referable, consumergenerated information on the Internet. Online Consumer Psychology: Understanding and Influencing Consumer Behavior in the Virtual World, 32, 35-61.

Sipe, L.J. (2018). Exploring Emotional Value in Memorable Guest Experiences: Insights from Dining, Lodging, Events and Attractions. Journal of Tourism \& Hospitality, 7(4), 1-6.

Sotiriadis, M. D., \& Van Zyl, C. (2013). Electronic word-of-mouth and online reviews in tourism services: the use of twitter by tourists. Electronic Commerce Research, 13(1), 103-124.

Sulek, J. M., \& Hensley, R. L. (2004). The relative importance of food, atmosphere, and fairness of wait: The case of a full-service restaurant. Cornell Hotel and Restaurant Administration Quarterly, 45(3), 235-247.

Sweeney, J. C., \& Soutar, G. N. (2001). Consumer perceived value: The development of a multiple item scale. Journal of Retailing, 77(2), 203-220.

Tadeja, K. (2008). The influence of perceived value on customer loyalty in Slovenian hotel industry. Turizam, (12), 12-15.

Vermeulen, I. E., \& Seegers, D. (2009). Tried and tested: The impact of online hotel reviews on consumer consideration. Tourism Management, 30(1), 123-127.

Wang, P. (2015). Exploring the influence of electronic word-of-mouth on tourists' visit intention: A dual process approach, Journal of Systems and Information Technology, 17(4), 381395.

Wang, Y., Po Lo, H., Chi, R., \& Yang, Y. (2004). An integrated framework for customer value and customer-relationship-management performance: a customer-based perspective from China", Managing Service Quality: An International Journal, 14(2/3), 169-182.

Westbrook, R. A. (1987). Product/consumption-based affective responses and post-purchase processes. Journal of Marketing Research, 258-270.

Woodruff, R. B. (1997). Customer value: the next source for competitive advantage", Journal of The Academy of Marketing Science, 25(2), 139.

Williams, P., \& Soutar, G. N. (2009). Value, satisfaction and behavioral intentions in an adventure tourism context. Annals of Tourism Research, 36(3), 413-438.

Wu, C. H. J., \& Liang, R. D. (2009). Effect of experiential value on customer satisfaction with service encounters in luxury-hotel restaurants. International Journal of Hospitality Management, 28(4), 586-593.

Xiang, Z., Schwartz, Z., Gerdes Jr, J. H., \& Uysal, M. (2015). What can big data and text analytics tell us about hotel guest experience and satisfaction? International Journal of Hospitality Management, 44, 120-13.

Xie, L., \& Chen, C. C. (2014). Hotel loyalty programs: how valuable is valuable enough? International Journal of Contemporary Hospitality Management, 26(1), 107-129.

Yang, F. X. (2017). Effects of restaurant satisfaction and knowledge sharing motivation on eWOM intentions: the moderating role of technology acceptance factors. Journal of Hospitality \& Tourism Research, 41(1), 93-127.

Yen, C. L. A., \& Tang, C. H. H. (2019). The effects of hotel attribute performance on electronic word-of-mouth (eWOM) behaviors. International Journal of Hospitality Management, 76, 9-18.

Yuksel, A., \& Rimmington, M. (1998). Customer-satisfaction measurement: Performance counts. Cornell Hotel and Restaurant Administration Quarterly, 39(6), 60-70.

Zehrer, A., Muskat, B., \& Muskat, M. (2014). Services research in tourism: Advocating the integration of the supplier side. Journal of Vacation Marketing, 20(4), 353-363.

Zeithaml, V. A. (1988). Consumer perceptions of price, quality, and value: a means-end model and synthesis of evidence. Journal of marketing, 52(3), 2-22. 